\title{
POLITIK ISLAM DALAM PUSARAN SEJARAH SURAKARTA
}

\author{
Hermanu Joebagio \\ Universitas Sebelas Maret \\ email: hermanu.joebagio@gmail.com
}

\section{ABSTRACT}

This article tries to analysis political strategy at the time of islamzation in 16th to 19th century. This analysis use political theory, it's descending and ascending of power. By supporting of the Saints, it's possible for Jin Bun (Raden Patah) built the Kingdomof Demak, and by supporting not only spread of islamization, but also reinforced political and social structure. Implication of that Islam was possible running embraces in Demak society. Conversion from Hindu to Islam could be investigation by language symbolism, for instance, the title of Ngabdurrahman Sayidin Panatagama Khalifatullah. Although the Kingdom of Demak had been collapsed, but islamization processes moved toPajang and than to the Palace of Mataram. Furthermore Sultanate of Mataram, Sultan Agung, introduceda new strategy for spread of islamization in Java, that were: (1) palaceas center ofIslamization, and (2) Islam center points of Javanese culture. The new strategy were continued of political strategy of the Saints. In the other side, Sultan Agung supported the Saints to built pesantren or madrasah (local boarding school) that had been a grassroots political legitimation. And a grassroot power based on values of solidarity or ashabiyyah.

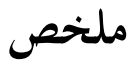

هذه المقالة تحاول أن تحلل استراتيجية سياسية في وقت أسلمة في القرن جا إلى القرن 9 و ـهذا التحليل استخدم النظرية السياسية،نظرية تنازلية وتصاعدية من السلطة. من خلال دعم القديسين، فمن الممكن لجين بون (رادينبناح)بناء محلكة ديماك، والدعم ليس فقط انتشار أسلمة، ولكن عزز أيضا الهيكل السياسي والاجتماعي. فمن هنايمكن الإسلام أن يشغل في أعتناقمجتمع ديماك. يمكن التحويلمن الهندوسية إلى الإسلام أن يكون تحقيقا من قبل رمزية اللغة، على سبيل المثال، عنوانعبد الرحمن 


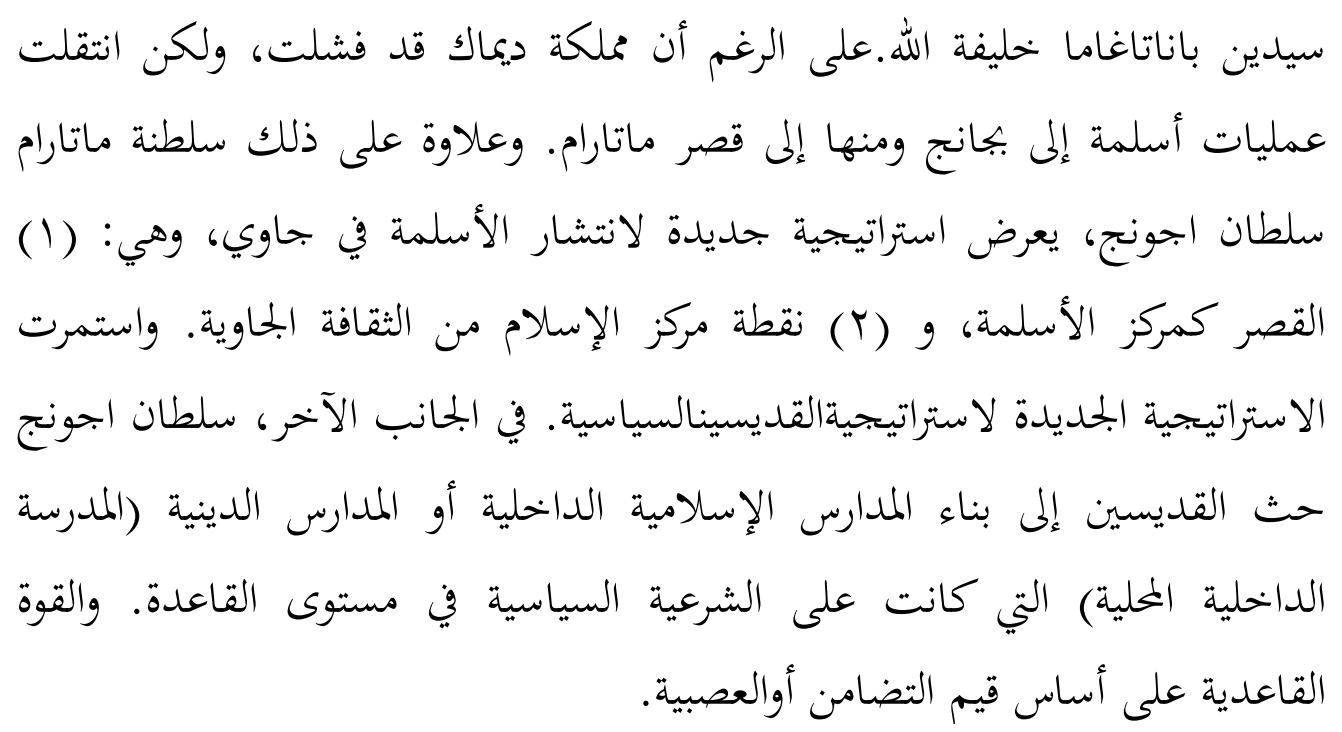

Keywords: islamization, descending and ascending of power, ashabiyyah.

\section{A. Pendahuluan}

Pelayaran para Sayyid (keturunan Rasulullah) menuju Kanton pada abad ke-7 diikuti ulama Sufisme. Mereka menyusuri Gujarat, Malabar, Coromandel, Selat Malaka, Vietnam, hingga Kanton, dan dari Selat Malaka itu para Sayyid dan Sufi memasuki Sumatra, Kalimantan, dan Jawa. ${ }^{1}$ Secara perlahan proses islamisasi itu memasuki jantung Kerajaan Majapahit, yang masa itu di bawah pemerintahan Raja Brawijaya V. Haji Gan Engcu dan Sunan Ampel dalam “Semarang Annals" bernama Bong Swi Hoo adalah tokoh yang memberi hadiah seorang putri bangsawan Champa bernama Dewi Kiem kepada Raja Brawijaya V sebagai strategi mempercepat proses islamisasi di Majapahit. ${ }^{2}$ Bong Swi Hoo

1 Banyak sumber menyebutkan bahwa penyebaran agama Islam berasal Gujarat, dan menafikan Islam berasal dari Timur Tengah. Lihat Azyumardi Azra, Jaringan Ulama Timur Tengah dan Kepulauan Nusantara Abad XVII dan XVIII: Akar Pembaharuan Islam Indonesia (Jakarta: Prenada Media, 2004); cf. Teungku Sayyid Deqy, Korpus Mapur dalam Islamisasi Bangka (Yogyakarta: Ombak, 2014).

2 Ketika Dinasti Ming (1368-1644) membentuk perwakilan dagang di Kerajaan Majapahit, pemerintah Cina menunjuk Haji Gan Engcu sebagai kepala perwakilan. Kedudukan Haji Gan Engcu di bawah kekuasaan Bong Tak-Keng yang berkedudukan di Champa, dan Bong Tak-Keng maupun Gan Engcu di bawah pengawasan Zheng He (Cheng Ho). Haji 
adalah seorang cucu penguasa tertinggi di Champa. ${ }^{3}$ Perkawinan dengan Dewi Kiem membuahkan tiga putra, yakni Swan Liong, Jin Bun (dikenal sebagai Raden Patah), dan Kin San. Ketika Raden Patah mendirikan Kerajaan Islam Demak, salah satu konsekuensinya membangun dunia politik agama disebut cuius regio eius et religio.

Dengan cara ini proses islamisasi tidak banyak hambatan, karena pada satu sisi raja beragama Islam, dan pada sisi lain adanya kecerdasan Sufi dalam berdakwah sehingga ajaran agama Islam lebih mudah diterima. ${ }^{4}$ Melalui cara itu ada tiga indikator yang mempercepat akselerasi konversi, yaitu: (1) keterbukaan masyarakat Majapahit terhadap sesuatu yang baru, (2) sajian dakwah atraktif yang menimbulkan decak kekaguman, dan (3) kecerdasan Sufi memanfaatkan budaya lokal dalam media dakwah mereka.

Konstelasi politik Majapahit yang sedang menghadapi keruntuhan akibat kehadiran Islam pada satu pihak, serta pada pihak lain lekatnya Islam dengan dunia politik adalah implikasi relasi intens antarulama dan aristokrat. Raden Patah yang dilahirkan dari keluarga Muslim sangat berkepentingan untuk mendirikan Kerajaan Islam Demak. Berdirinya kerajaan merupakan primus inter pares bagi kerajaan berikutnya. Simbol primus inter pares terlihat dari sisi bahasa, dan simbol itu kemudian ditransformasikan pada gelar kekuasaan raja, misalnya sebutan Ngabdurrahman Sayidin Panatagama Khalifatullah.

Gelar kekuasaan menunjukkan betapa besarnya kekuasaan raja. Bila gelar itu ditransformasikan dalam simbol publik menunjukkan tumbuhnya dialektika struktur relasi antarindividu, rakyat dan pemerintah. Sementara itu dialektika ulama diletakan ditengah relasi politik antara rakyat dan pemerintah. Model ini pada satu sisi berperan untuk melegitimasi kekuasaan, dan pada sisi

Gan Engcu berwenang untuk mengawasi seluruh aktivitas politik dan ekonomi (dagang), serta mengawasi komunitas imigran Tionghoa agar tetap mendukung kepentingan negeri mereka di Tiongkok meskipun bertempat tinggal di Majapahit. Lihat Syuan-yuan Chiou, "Contested Legacies of Chinese Muslims and the Appropriation of Zheng He's Muslim Images in Contemporary Indonesia", dalam Ota Atsushi, Okamoto Masaaki, and Ahmad Suaedy (eds.), Islam in Contention: Rethinking Islam and State in Indonesia (Jakarta: Wahid Institue-CSEAS Kyoto University-CAPAS Nanyang, 2010), hal. 321-326.

3 Ibid, hal. 325-326; cf. Benny G. Setiono, Tionghoa dalam Pusaran Politik (Jakarta: Trans Media, 2008), hal. 45-49

4 A.H. Johns, "Muslim Mystics and Historical Writing", dalam D.G.E. Hall (ed.) Historians of South East Asia (London: Oxford University Press, 1961), hal. 10-23. 
lain menempatkan ulama dalam peran sebagai arbitrase konflik. Struktur relasional ini dipersepsikan rakyat menungkinkan tumbuhnya harapan baru untuk membentuk sebuah tatanan sosial baru. ${ }^{5}$

Dalam perkembangannya terjadi ketimpangan relasi politik, karena pandangan elit bahwa agama adalah alat politik. Ketika pandangan diletakan pada alat politik, tentu akan timbul penyalahgunaan kekuasaan untuk mendomestikasi kelompok oposisi yang berseberangan dengan kebijakan pemerintah. Semakin tinggi domestikasi terhadap agama dan perangkatnya, semakin tumbuhnya sinergi antara kelompok oposisi dan ulama. Inilah titik awal titik temu yang saling membutuhkan antara oposisi dan ulama. ${ }^{6}$ Menjelang keruntuhan Majapahit, kondisi ini dimanfaatkan Raden Patah untuk mendirikan Kerajaan Islam Demak. Relasi antararistokrat dan ulama justru membentuk konfigurasi kesederajatan politik. Persoalannya, mengapa kesederajatan politik dalam descending of power cepat berakhir, dan mengapa dalam waktu bersamaan tumbuh ascending of power?

\section{B. Politik Islam di Demak}

Politik adalah sebuah perjuangan meraih dan membentuk kekuasaan. Usaha meraih kekuasaan dilandasi oleh ide atau gagasan pemikiran agama. Meraih kekuasaan bisa simetris dan asimetris. Apabila simetris implikasinya negara berbasis ideologi agama, sebaliknya bila asimetris negara tidak menggunakan ideologi agama sebagai basis kebijakan politik. Karena itu Islam dan politik sering dipahami dalam dua paradigm istilah, yaitu Islam politik dan politik Islam. Politik Islam adalah praktik kenegaraan dengan memanfaatkan Islam sebagai alat politik, sedangkan Islam politik adalah praktik kenegaraan berbasis ideologi agama Islam. Argumentasi Islam sebagai alat politik, karena dalam bingkai ajaran Islam terkandung nilai-nilai taqwa (loyalitas), asshabiyyah (solidaritas), dan semangat korsa yang berfungsi sebagai kekuatan untuk membangun kesatuan politik. ${ }^{7}$

5 Dale F. Eickelman \& James Piscatori, Politik Muslim: Wacana Kekuasaan dan Hegemoni dalam Masyarakat Muslim (Yogyakarta: Tiara Wacana, 1998), hal. 3-13.

6 H.J. de Graff \& Th.G.Th. Pigeud, Kerajaan-kerajaan Islam di Jawa: Peralihan dari Majapahit ke Mataram (Jakarta: Grafiti Pers, 1985), hal. 63-72.

7 Ibn Khaldun, Muqaddimah (Jakarta: Pustaka Firdaus, 1986), hal. 166-167; cf. Faisal Is- 
Historiografi Indonesia menjelaskan islamisasi merupakan suatu produk interaksi simbiosis antarkelompok politik dan ulama karena antarmereka saling membutuhkan. Ulama membutuhkan elit untuk memberi izin memperluas dakwah keagamaan, dan elit politik memanfaatkan ulama untuk legitimasi kekuasaan. Dengan dasar asumsi itu, Raden Patah adalah elit politik yang memanfaatkan dakwah agama sebagai basis kekuatan politik. Sinergi antarmereka ulama dalam perspektif ilmu politik disebut descending of power ${ }^{8}$.

Dengan demikian descending of power merupakan sistem politik dipengaruhi oleh agama. Dalam sistem ini ulama berfungsi memberi fatwa terhadap kebijakan raja, dan fatwa politik itu digunakan untuk menilai kebijakan raja sejauhmana berdampak terhadap instabilitas politik dan keamanan. Ulama bisa meminta untuk membatalkan kebijakan raja apabila tidak berkontribusi kepada rakyat. Sebaliknya, kebijakan didukung bila berfungsi menjaga keutuhan negara, meskipun tidak pro rakyat. Ulama akan memastikan apakah kebijakan itu eksploitatif, atau sekadar kepentingan sepihak. Campur tangan ulama dalam politikmenjadi transendensi politik Raden Patah, karena pada satu sisi mempertimbangkan prinsip etika dan moral, pada sisi lain adalah legitimasi politik dari ulama dan basis massanya ulama. ${ }^{9}$

Transpolitika keagamaan Raden Patah mengikuti model descending of power, dan mengaplikasikan antara dunia kekuasaan dan dunia produksi untuk peningkatan kesejahteraan rakyat. Dengan dasar transpolitika itu, Raden Patah memilih prinsip umur al-dunya-umur al-din (pemisahan urusan dunia dan agama). Realisasi prinsip itu justru memicu tumbuhnya perekonomian Pantai Utara Jawa. ${ }^{10}$ Elit politik menyadari bahwa tumpuan negara terletak pada: (1) moralitas agama yang diajarkan ulama, (2) kekuatan perdagangan Muslim sebagai dinamika pertumbuhan ekonomi, dan (3) kekuatan massa politik yang memberi dukungan terhadap eksistensi kerajaan. Ketiga komponen itu sebagai proses konsolidasi yang terintegrasi antara dagang, kekuasaan, dan agama yang

mail, Pijar-Pijar Islam: Pergumulan Kultur dan Struktur (Yogyakarta: LESFI, 2004), hal. 15-16.

8 Bryan S. Turner, Agama dan Teori Sosial (Yogyakarta: Ircisod, 2006), hal. 306-307.

9 Yasraf A. Piliang, Transpolitika: Dinamika Politik di dalam Era Virtualitas (Yogyakarta dan Bandung: Jalasutra, 2006), hal. 1-9.

10 Zainuddin Maliki, Agama Priyayi: Makna Agama di Tangan Elite Penguasa (Yogyakarta: Pustaka Marwa, 2004), hal. 50. 
implikasinya tumbuhnya struktur masyarakat egalitarian dan kosmopolitan. ${ }^{11}$ Struktur masyarakat egalitarian dan kosmopolitan merupakan perspektif mulk, karena antara syariah dan siyasah aqliyah (politik rasional) saling mencari modus vivendi. ${ }^{12}$

Dalam descending of power, ulama wakil rakyat dalam penyaluran aspirasi, dan dalam kasus Demak tidak dapat ditafsirkan sebagai kekuasaan negara di bawah bayang-bayang ulama. Problem utamanya aristokrat dan ulama ingin membangun relasi politik, dan mengendalikan kekuasaan absolut raja. Implikasi negatif, descending of power adalah tidak membuka ruang partisipatif. Penguasa Perancis Louis XIV bahkan mengucapkan l'etat c'est moi, sebuah perwujudan kekuasaan absolut.

Religiusitas ulama beserta arbitrasenya menjamin harmonisasi diamika politik, karena itu ulama berada ditengah penyelesaian kebuntuan politik. Religiusitas peran ulama memicu perubahan psikologi politik. ${ }^{13}$ Kedekatan ulama dan rakyat adalah konsekuensi islamisasi, di samping ulama pengelola lembaga masjid dan pesantren. Peran arbitrase ulama memang menjamin kestabilan politik dan keamanan pada awal dekade Kerajaan Islam Demak, tetapi pada dekade berikutnya peran ulama mengalami proses pasang surut. Dalam perspektif politik kestabilan dan keamanan tercipta karena adanya relasi-relasi yang mengesankan antarlembaga politik, peran pedagang, dan partisipasi politik masyarakat. ${ }^{14}$ Kala itu elemen-elemen politik yang terdiri dari elit, ulama, rakyat dan pemerintahan berhasil membentuk kesatuan politik Kerajaan Demak.

Sistem descending of power di Kerajaan Islam Demak tidak berlangsung lama, karena terkoyak oleh instabilitas politik. Ada dua faktor penyebab, Pertama, besarnya intrik, provokasi, dan faksionalisme di lingkungan istana. Fenomena ini akibat besarnya jumlah putera raja. Masing-masing berkepentingan meraih kekuasaan. Pada sisi lain, aristokrat yang berseberangan dengan kebijakan raja

11 Taufik Abdullah, Islam dan Masyarakat: Pantulan Sejarah Indonesia (Jakarta: LP3ES, 1987), hal. 119-121.

12 Ibid., hal. 129-138.

13 H.J. de. Graaf, Puncak Kekuasaan Mataram: Politik Ekspansi Sultan Agung (Jakarta: Pustaka Grafitipers, 1986), hal. 203-204.

14 Arbi Sanit, Sistem Politik Indonesia: Kestabilan, Peta Kekuatan Politik dan Pembangunan (Jakarta: Rajawali Pers, 1982), hal. 15-27. 
distigma sebagai oposisi. Mereka kemudian disantrikan untuk memperdalam ilmu agama Islam di pesantren pilihan raja. ${ }^{15}$ Makna marjinalisasi itu justru menguntungkan proses islamisasi. Penyantrian akan memacu tumbuhnya konflik antara aliran traditional Javanese mysctism dan orthodox legalistic Islam. ${ }^{16}$ Implikasi kasus penyantrian anak-pinak mereka pada abad ke-19 melancarkan gerakan protes berideologi Islam, ${ }^{17}$ dan gerakan itu merupakan embrio gerakan kebangsaan abad ke-20. ${ }^{18}$

Kedua, di lingkaran ulama timbul perdebatan tentang urgensi keterlibatan ulama dalam kegiatan politik praktis di Kerajaan Demak. Salah satu ulama penentang adalah Sjech Siti Jenar. ${ }^{19}$ Dia berpendapat ulama harus bisa memisahkan antara kepentingan dunia dan agama. Siti Jenar khawatir "tangan suci ulama terbelit oleh kotoran darah". Inti dari pemikiran Sjech Siti Jenar terfokus pada persoalan kesalehan personal, bukannya kesalehan sosial yang dibutuhkan masyarakat. Pemikiran Sjech kemudian dijadikan pedoman elit politik untuk memutus rantai relasi politik dengan ulama, dan membangun struktur politik baru disebut manunggaling kawula gusti.

Sjech Siti Jenar menginginkan reposisi ulama berpijak pada filsafat perennial (philosophia perennis). Dia menyarankan ulama berpegang pada simbol generik Islam. Inti simbol itu adalah sikap pasrah dan taqwa, serta menghayati kehadiranNya (omnipresent) dalam kehidupan sehari-hari. ${ }^{20}$ Perdebatan antara Sjech Siti Jenar dan ulama dapat disimpulkan penulis bahwa hidup di alam semesta secara objektif tidak hanya menempatkan diri pada persoalan-persoalan kesalehan personal, tetapi ulama harus bisa membangkitkan umat untuk

15 Taufik Abdullah, Islam dan Masyarakat, hal. 139-144.

16 S. Soebardi, "Santri-religious Elements as Reflected in the Book of Tjentini", Bijdragen tot de Taal-, Land-en Volkenkunde (BKI), No. 127, 1971, hal. 349.

17 Vincent J.H. Houben, Keraton dan Kompeni: Surakarta dan Yogyakarta 1830-1870 (Yogyakarta: Bentang Budaya, 2002), hal. 437-452.

18 Sartono Kartodirdjo, Protest Movement in Rural Java: A Study of Agrarian Unrest in the Nineteenth and Early Twentieth Centuries (Kuala Lumpur: Oxford University Press, 1978), hal. 210-213.

19 M.C. Ricklefs, Yogyakarta di bawah Sultan Mangkubumi1749-1792 (Yogyakarta: Mata Bangsa, 2002), hal. 9-11.

20 Budhy Munawar-Rachman, Islam Pluralis: Wacana Kesetaraan Kaum Beriman (Jakarta: Raja Grafindo Persada, 2004), hal. 101-104. 
menghadapi tantangan dunia (kesalehan sosial). Melalui cara semacam itu masyarakat Islam mudah diberdayakan.

Pemikiran Sjech Siti Jenar dalam perspektif ilmu politik merupakan gagasan ascending of power atau umur al-dunya-umur al-din (pemisahan urusan dunia dan agama). Pemikiran Sjech identik dengan sekularisme di abad modern, dan sekularisme merupakan salah satu syarat tumbuhnya demokrasi politik. Pada sisi lain, pemikiran Sjech justru dipersepsikan terbalik oleh elit politik, mereka berpandangan bahwa pemisahan itu manifestasi dari pemutlakan kekuasaan Illahiah.

Pembalikan pemikiran Sjech Siti Jenar sangat jelas ketika Sultan Agung wafat. Amangkurat I dan Amangkurat II berkuasa secara Illahiah. Mereka memarjinalkan ulama dengan dalih kongregasi politik. Marjinalisasi ulama meneguhkan kesediaan masyarakat desa berada di bawah bayang-bayang ulama. Marjinalisasi dapat memicu konversi kongregasi, yakni dari agama ke politik, karena para ulama dimungkinkan untuk membangun persepsi politik di ruang publik mereka. ${ }^{21}$ Konversi itu yang paling ditakuti oleh elit politik, karena mendorong tumbuhnya pemikiran kuasa tandingan, bahkan bisa melemahkan kekuasaan Illahiah raja. Elit aristokrat tidak sadar bahwa kongregasi politik merupakan esensi dari Islam.

\section{Kekerasan Politik}

Perpindahan kerajaan dari kawasan pantai menuju pedalaman Jawa Tengah (Surakarta-Yogyakarta) identik meninggalkan budaya egalitarian dan kosmopolitian. Mereka merubah diri dari masyarakat pantai yang terbuka menjadi masyarakat tertutup dengan kehidupan agraris. Namun, perpindahan itu tetap menjaga relasi politik antarraja dan ulama. Bahkan relasi itu direproduksi Sultan Agung dalam suatu strategi bahwa keraton sebagai agen islamisasi di Jawa, dan Islam wahana rekonsiliasi budaya Jawa. ${ }^{22}$

${ }^{21}$ Perubahan menjadi kongregasi politik berpijak pada suhal.y-side theory, dan bukannya demand-side theory. Eksistensi lembaga keagamaan adalah permintaan publik, begitu pula dorongan terhadap ulama untuk melakukan kongregasi politik. Lihat Pippa Norris \& Ronald Inglehart, Sekularisasi Ditinjau Kembali: Agama dan Politik di Dunia Dewasa Ini (Jakarta: Pustaka Alvabet \& Paramadina, 2009), hal. 8.

22 M.C. Ricklefs, "Islamising Java: The Long Shadow of Sultan Agung", Archipel, Vol. I, 
Arti reproduksi adalah, pertama menjadikan istana sebagai pusat kajian ilmu agama Islam. Implikasinya reproduksi ini adalah Islam sebagai kekuatan politik, sekaligus alat politik. Elit politik harus bersedia hidup berdampingan dengan ulama di samping sebagai alat legitimasi politik dan moral. ${ }^{23}$ Kedua, dengan legitimasi politik dan moral menunjukkan adanya pengakuan ulama terhadap eksistensi kekuasaan Sultan Agung. Meski Sulatan Agung gagal dalam penyerbuan di Batavia, dan muncul kelompok oposisi, tetapi ulama tetap memberi pengakuan dan memerankan sebagai arbitrase konflik dengan kelompok oposisi. Ketiga, sisi negatif reproduksi Islam yang dilakukan Sultan Agung justru semakin kokohnya sintesis sinkretik. ${ }^{24}$

Sepeninggal Sultan Agung relasi politik antara raja dan ulama berakhir, meskipun dalam birokrasi kerajaan masih dipertahankan reh-pengulon (lembaga kegamaan istana). Pembunuhan ratusan ulama dan santri di alun-alun Pleret oleh Amangkurat I menunjukkan kongregasi politik terus berlangsung, terutama ketika terjadi suksesi. ${ }^{25}$ Amangkurat I dipandang tidak memiliki kapabilitas, bahkan moral pun tidak memadai, dan hanya Pangeran Alit dipandang ulama berkapabilitas. Persepsi ulama ini mode kanalisasi politik berbasis publik (plebiscitary), dan mode kanalisasi politik itu pernah dilakukan orde baru dalam menghadapi pemilihan umum. ${ }^{26}$

Represi politik terhadap ulama memaksanya menyingkir dan tinggal di pedesaan jauh dari pusat istana. Di tempat baru itu ulama memerankan seba-

No. 56, 1998, hal. 469-482.

23 Abdurrahman Mas'ud, Intelektual Pesantren: Perhelatan Agama dan Tradisi (Yogyakarta: LKiS, 2004), hal. 55-58; M.C. Ricklefs, The Seen and Unseen Worlds in Java 1726-1749: History, Literature and Islam in the Court of Pakubuwana II (Honolulu: Allen \& Unwin, and University of Hawai'i Press, 1998), hal. xvii-xix.

${ }^{24}$ Sintesis sinkretik konsekuensi bertahannya tradisi Hindu-Buddha di istana. Sintesis sinkretik adalah esensi budaya masyarakat, dan realitas religius itu merupakan warna keagamaan yang belum berjalan secara linear. Warna Islam melewati transisi secara berkelanjutan. Lihat Julian Millie, Splashed by the Saint: Ritual Reading and Islamic Sanctity in West Java (Leiden: KITLV Press, 2009), hal. 8.

25 Karel A. Steenbrink, Beberapa Aspek tentang Islam di Indonesia Abad ke-19 (Jakarta: Bulan Bintang, 1984), hal. 30.

26 Dodi Ambardi dalam laporan utama Tempo menguraikan kepolosan blusukan Jokowi sebagai mode kanalisasi politik (plebiscitary) yang berimbas pada capaian meteorik di pentas politik nasional. Kanalisasi politik juga pernah dilakukan orde baru. Lihat Tempo, Edisi 5-11 Agustus 2013, hal. 42-43. 
gai cultural broker, memberdayakan masyarakat, dan membangun komunitas epistemik. ${ }^{27}$ Peran cultural broker itu ulama menjadi elit agama sekaligus elit politik. Peran ini simbolisasi pencanangan diri sebagai oposisi, dan akan membela rakyat bila terrepresi secara terus menerus. Pada dasarnya represi politik akan memacu tumbuhnya polarisasi kekuatan ulama, yakni: (1) ulama nonbirokrasi dan guru agama yang berada di pedesaan, dan ulama birokrasi bertahan di istana.

Sejatinya ulama non-birokrasi dan guru agama yang paling berhasil mengubah mengonversi dan merubah persepsi kosmologi Muslim. Semula kosmologi diletakan pada kesaktian raja, dan setelah konversi menempatkan pada kosmologi Makkah. ${ }^{28}$ Pengalihan pusat kosmologi adalah kesadaran bahwa kekuasaan hakiki berada di tangan Allah Swt. Muslim sadar bahwa eksistensi diri mereka terletak pada kemampuan mengolah self-reliance, self-sufficiency, self defence, dan pengembangan kreativitas pribadi. ${ }^{29}$ Keempat faktor itu adalah senjata yang paling jitu dalam menghadapi represi, subordinasi, dan containment policy. ${ }^{30}$

Represi terhadap Muslim terekam dalam Manuskrip Jawa, baik dalam $B a-$ bad Pakepung, Serat Centhini, maupun Serat Cebolek. Represi menyebar di seluruh komponen lembaga keagamaan, dan realitas ini menciptakan segregasi sosial maupun segregasi politik. Segregasi sosial maupun politik justru dapat memperlemah ketahanan masyarakat berkaitan dengan prinsip pemberdayaan, disebut civic engagement dan political engagement. ${ }^{31}$ Pada masa kolonial, Muslim

27 Yudi Latif, Inteligensia Muslim dan Kuasa: Genealogi Inteligensia Muslim Indonesia Abad ke-20 (Bandung: Mizan, 2005), hal. 11-58; Fachry Ali, “Masa Tak Berwarga Negara: Gerakangerakan protes di Jawa Abad Ke-19”, dalam Asep Gunawan (ed.), Artikulasi Islam Kultural: Dari Tahapan Moral ke Periode Sejarah (Jakarta: Raja Grafindo Persada, 2004), hal. 237-261.

28 Matin van Bruinessen, Kitab Kuning: Pesantren dan Tarekat (Yogyakarta: Gading Publishing, 2012), hal. 3-4.

29 Kamdani (peny.), Islam dan Humanisme: Aktualisasi Humanisme Islam di Tengah Krisis Humanisme Universal (Yogyakarta: Pustaka Pelajar, 2007), hal. 15.

30 Contaiment policy merupakan kebijakan raja untuk mengurung ulama dengan memberikan tanah perdikan untuk mendirikan lembaga masjid dan pesantren. Pengurungan ini merupakan bentuk pengendalian ulama dan basis massa untuk tidak memerankan diri sebagai oposisi. Lihat Karel A. Steenbrink, Beberapa Aspek tentang Islam di Indonesia, hal. 2930.

31 Civic engagement adalah bangunan tumbuhnya relasi anrtarwarganegara, dan political engagement bangunan tumbuhnya sifat kritis terhadap kebijakan publik yang dikeluarkan 
yang tinggal di sekitar pesantren dan dipandang bukan warganegara Hindia Belanda, dan persepsi pejabat kolonial ini merupakan bentuk segregasi sosial. ${ }^{32}$ Segregasi sebuah fenomena benturan antara penganut ortodoksi dan sinkretik. Pemerintah kolonial tidak suka tumbuh ortodoksi di Hindia Belanda. Meluasnya ortodoksi diartikan sebagai pemupukan watak melawan. ${ }^{33}$ Penguasa tidak sadar bahwa watak itu timbul akibat penguasa mengingkari kewajiban untuk melindungi, menyejahterkan, dan memberi jaminan keamanan terhadap masyarakat. ${ }^{34}$ Interpretasi segregatif merupakan perilaku kolonialis yang tidak dapat dipertanggungjawabkan.

Agama Islam menjunjung keluhuran hidup yang secara implisit terkandung dalam universalisme Islam, yakni hifdz ad-dìn, hifdz al-'aql, hifdz al-māl, hifdz an-nafs, dan hifdz an-nasl. Universalisme menempatkan Muslim sebagai katalisator perdamaian dan harmoni terhadap alam semesta. Universalisme itu adalah prinsip rahmatan lil alamin, dan dengan demikian tidak dibenarkan adanya relasi sosial dan politik yang hegemonik. Refleksi katalisator adalah kewajiban bagi Muslim untuk menjamin, melindungi, dan menyejahterakan tanpa memandang suku, agama, ras, dan aliran.

Represi dan stigma menyebabkan tumbuhnya masyarakat subaltern. Subaltern merujuk pada kelompok sosial yang terrepresi dan termarjinalisasi secara politik. Stigma menunjukkan tidak akan memberi ruang publik, dan hal itu selalu dilakukan secara kekerasan. ${ }^{35}$ Hilangnya ruang publik berakibat semakin tidak berdayanya mereka berhadapan dengan kekuasaan. Oleh karena itu kesalehan sosial wajib melekat dalam diri ulama dan elit politik. Kesalehan sosial berfungsi sebagai peneguhan pemberdayaan serta pengendalian nafsu berkuasa. Elit harus sadar pentingnya kemajuan dan persatuan, taqaddum wa al-ittihad, mengingat kemajuan dan bersatu adalah idealisasi sebuah kesejahteraan.

pemerintantah. Lihat Saiful Mujani, Muslim Demokrat: Islam, Budaya Demokrasi, dan Partisipasi Politik di Indonesia Pasca-Orde Baru (Jakarta: Gramedia Pustaka Utama, 2007), hal. 26-29.

32 C.A.O. van Nieuwenhuijse, Aspect of Islam in Post-Colonial Indonesia (The Hague \& Bandung: W. van Hoeve, 1958), hal. 1-31.

${ }_{33}$ Abdurrahman Wahid, "Martin van Bruinessen dan Pencariannya: Kata Pengantar", dalam Martin van Bruinessen, Kitab Kuning: Pesantren dan Tarekat, hal. xi-xv.

${ }^{34}$ Ibid.

${ }^{35}$ I Ngurah Suryawan, Genealogi Kekerasan dan Pergolakan Subaltern: Bara di Bali Utara (Jakarta: Predana Media, 2010), hal. 20-21. 
Rendahnya taqaddum wa al-ittihad berdampak lunturnya pemberdayaan ekonomi dan politik. Refleksi sejarah menunjukkan kekuasaan Illahiah tidak pernah bertanggungjawab terhadap kebijakan publik yang diberlakukan. ${ }^{36}$ Banyak pejabat melakukan tindakan a-patriotik, berkarakter ganda sebagai aparatur pemerintah, dan banyak di antara merka yang tidak mampu melaksanakan tata kelola administrasi pemerintahan di daerah maupun di pusat. ${ }^{37}$ Mereka memungut dan memanipulasi pajak untuk kepentingan pribadi, sekaligus mereka sebagai penjaga ketertiban umum dan berkuasa atas nama peradilan. Karakter aparatur semacam itu dipastikan sering melakukan tindak kekerasan, ${ }^{38}$ dan mereka pejabat nomadism dan schizophrenia. ${ }^{39}$

Nomadism merujuk lemahnya jati diri dan identitas elit, sedangkan schizophrenia merujuk pada keterbelahan diri pribadi, akibat kegalauan identitas, nilai, dan kesalahan memaknai politik kekuasaan. Nomadism dan schizophrenia implikasi dari tingginya hasrat berkuasa. Dan, hasrat berkuasa memupuk keuntungan pribadi tanpa aspirasi maupun idealisasi menunjukkan wajah dan jiwa immoral. Akhirnya, mereka tidak dapat membedakan antara res-privata dan res-publica.

\section{Kekerasan dalam Guratan Pujangga}

\section{Serat Iskandar}

Serat Iskandarsalah satu manuskrip Jawa mengungkap sifat elit politik yang “ilang sirnaning manembah", dan dimaknai sebagai hilangnya jati diri. Penelusuran Goenawan Mohamad terhadap ilang sirnaning manembah pada abad XVIII dan XIX teramati dalam Serat Wedatama, sebuah karya sastra Mangkunegara

36 Kekuasaan Illahiah adalah hasrat. Hasrat manusia adalah refleksi antara rasa kurang (lack), pemenuhan kebutuhan (need), dan keingian (want). Hasrat manusia dalam paradigma Islam diseleksi melalui proses pembatasan, penekanan dan pengendalian. Hanya hasrat tertentu yang dapat dipenuhi, dan manusia yang berhasrat melampaui batas kewajaran identik dengan menafikan otoritas Allah swt. Lihat "Kala Hasrat Menggoda: Catatan dari Editor", dalam Alfathri Adlin (ed.), Menggeledah Hasrat: Sebuah Pendekatan Multi Perspektif (Yogyakarta: Jalasutra, 2006), hal. xvi-xviii.

37 Willem Remmelink, Perang Cina dan Runtuhnya Negara Jawa 1725-1743 (Yogyakarta: Jendela, 2002), hal. 3-30.

38 Ibid.

39 Yasraf A. Piliang, Transpolitika, hal. 155-157. 
IV. ${ }^{40}$ Analisis Goenawan Mohamad terhadap Serat Wedatama selaras dengan pemikiran Kanjeng Ratu Mas Balitar dalam Serat Iskandar. Serat Iskandar ditulis Kanjeng Ratu Mas Balitar (Permaisuri Paku Buwana I) memandang elit politik tidak mempunyai keberanian menghadapi kompeni. Mereka menjadi peragu dalam menentukan sikap dan tindakan politik, meskipun kekuatan kompeni saat itu sangat lemah. ${ }^{41}$

Pesan moral Serat Iskandar menjadi semu, karena satria Jawa lebih senang menikmati kebesaran, dan bersanding dengan kompeni. Mereka terjerumus pandangan bahwa: (1) aristokrat berhak meraih kekuasaan, dan kekuasaan relevan dengan kepentingan individu; (2) aristokrat tidak pernah memikirkan negara dalam kondisi rapuh, bahkan antarkomponen politik di kerajaan terpisah. Gejala politik itu mendorong mereka mengutamakan kepentingan intrinsik, dan tidak melihat kepentingan negara atau rakyat; dan (3) pengawasan raja terhadap putera-puteranya sangat lemah.

Di masa lalu satria adalah pusaka, dan dalam perkembangannya satria bukan milik arisokrat, tetapi menjadi bagian dari kehidupan masyarakat pinggiran yang jauh dari pusat kekuasaan. Pelopor transformasi satria justru berada ditangan ulama, dan dia memerankan diri sebagai cultural brokers bagi masyarakat pedesaan. Bila Serat Iskandar dihubungkan dengan pemikiran Sayyid Hossein Nasr bermakna sebagai alat penyadaran, recollection dan reawakening. ${ }^{42}$ Kanjeng Ratu Mas Balitar menolak tunduk kepada kompeni, dan dia mengkritik Paku Buwana II dan elit lainnya yang tunduk kepada penguasa kolonial. Ketertundukan itu menyebabkan hilangnya etika dan moral politik.

\section{Serat Cabolek}

Serat Cabolek adalah karya sastra yang mengungkap gerakan pembangkangan agama. Timbul gerakan akibat krisis ekonomi, politik, maupun sosial. Krisis

40 Goenawan Mohamad, "Paradigma Pengging: Kata Pengantar", dalam Nancy K. Florida, Menyurat yang Silam Menggurat yang Menjelang: Sejarah sebagai Nubuat di Jawa Masa Kolonial, terj. Revianto B. Santosa \& Nancy K. Florida (Yogyakarta: Bentang Budaya, 2003), hal. xiv-xvi.

41 Willem Remmelink, Perang Cina dan Runtuhnya Negara Jawa, hal. 151-218.

42 Azyumardi Azra, Historiografi Islam Kontemporer, (Jakarta: Gramedia Pustaka Utama, 2002), hal. 202. 
mendorong individu untuk menjelajahi dimensi spiritualitas "baru". Dimensi spiritualitas benar bila diletakan pada filosofi perennial (philosophia perennis). Melalui filosofi perennial terpahami betapa besar dan kompleksitas agama. Agama yang dipeluk bisa menunjukkan sifat yang relatif, terbatas, parsial, dan tidak lengkap. ${ }^{43}$ Agama berbentuk dan bersubstansi tidak sekadar skriptualis, tetapi juga kontekstualis. Substansi agama hadir dalam kehidupan individu berbentuk terbatas. Dengan demikian agama bisa bersifat universal, sekaligus bersifat partikular. Selanjutnya bentuk menjadi relatif, meskipun kandungan substansial bersifat mutlak. Penempatan filsafat dalam memahami agama adalah untuk menghindari pandangan sempit, sehingga agama berperan sebagai pemberdaya dan pembebas seluruh persoalan kehidupan sosial.

Serat Cabolek dideskripsikan sebagai perdebatan antara Ketib Anom Kudus dengan Haji Mutamakin. ${ }^{44}$ Perdebatan antara aliran Mistik Islam dan ortodoksi itu tidak mungkin bisa dipertemukan. Ketib Anom Kudus berdebat di seputar persoalan Kitab Rama, Arjunawiwaha, dan Bima Suci. Dan, perdebatan tersebut tidak menyentuh ujung-pangkalnya, karena perbedaan aliran keagamaan. Haji Mutamakin berpegang pada al-Quran dan al-Hadits, yang tentunya tidak mungkin bisa dikonversikan dengan kitab acuan Ketib Anom Kudus.

Amangkurat IV tidak membela Ketib AnomKudus karena terburu wafat sebelum memutuskan. Paku Buwana II memutuskan win-win solution. Dia sadar perdebatan itu tidak ada manfaatnya. Selayaknya Haji Mutamakin tidak menjawab, karena kitab Rama, Arjunawiwaha, dan Bima Suci adalah kitab epos yang menampilkan heroisme tokoh, meskipun di dalamnya terkandung filsafat kehidupan.

\section{Babad Pakepung}

Babad Pakepung dalam pupuh I dhandhanggula, pupuh II asmaradana, dan pupuh III sinom tersirat bahwa Paku Buwana IV mengangkat beberapa ulama karismatik sebagai penasihat politik dan penasehat agama. Interpretasi terhadap babad ini bisa beraneka ragam. Kehadiran ulama karismatik dalam birokrasi politik kerajaan menimbulkan kekhawatiran Mangkunegara, Sultan Yogyakarta, dan

43 Budhy Munawar-Rachman, Islam Pluralis, hal. 102-117.

44 S. Soebardi, Serat Cabolek: Kuasa, Agama, dan Pembebasan (Bandung: Yayasan Nuansa Cendekia, 2004), hal. 58-63. 
pemerintah Belanda. Paku Buwana IV dituduh oleh mereka melakukan penggalangan kekuatan politik untuk menyatukan Mataram.

Pemikiran Paku Buwana IV, kerajaan yang rapuh akibat palihan nagari membutuhkan konsolidasi politik melalui pembangunan ikatan politik dengan ulama beserta basis pesantren. Melalui konsolidasi itu diharapkan tumbuh keseimbangan politik antarkerajaan palihan nagari. Pemikiran equilibrium politik ini justru ditafsirkan berbeda. Akhirnya Hamengku Buwana I, Mangkunegara I, dan pemerintah Belanda bersinergi mendesak Paku Buwana IV untuk menghukum para ulama penasehat politik raja. Mereka adalah Kiai Panengah, Wiradigda, Nursaleh, Bahman, R. Santri, dan Kandhuruan.

Konflik antarelit di atas dapat dimaknai, pertama, sebuah konflik aliran antara traditional Javanese mysticism (Islam sinkretik) dan orthodox legalistic Islam. Konflik ini sudah berlangsung cukup lama sejak zaman Kerajaan Islam Demak. Pada sisi lain, pemerintah Belanda memilih melestarikan aliran traditional Javanese mysticism, dan dengan begitu Islam tetap terserak menjadi kekuatan kecil yang tidak berdaya berhadapan dengan bangsa kolonial. Kedua, kekuatan ortodoksi justru berpihak kepada Paku Buwana IV. Sementara itu Hamengku Buwana I dan Mangkunegara I memandang keberadaan ulama di istana menimbulkan diskonsiliasi dan disharmoni antaraliran. Islam sinkretik lebih diterima, karena bingkai kepercayaan Hindu dan Budha.

Konflik politik di Vorstenlanden sepanjang abad ke-19 menyeret Islam pada pusaran konflik. Paku Buwana IV lebih suka menggunakan simbol Islam untuk menyelesaikan persoalan konflik, sedangkan lawannya memilih safety first untuk kepentingan pribadi. Sejatinya, konflik bermakna positif dan negatif. Makna positif, Islam secara normatif-doktrinal tidak memasung kreativitas pengembangan doktrin dan ajaran Islam, sejauh tidak bertentangan dengan ketentuan dasar agama Islam. Namun demikian, kreativitas itu tergantung tingkat kemampuan berpikir Muslim.

Sisi negatifnya adalah timbul stigma the others, liyan (bahasa Jawa). Stigma ini merupakan konsep pemisahan, yang memacu segregasi, dan realitas segregatif mendorong timbulnya benturan sosial dan politik. ${ }^{45}$ Pemikiran segregasi merupakan akibat dari padatnya hierarkhi yang memperlebar pelapisan-

45 Joost Cote \& Loes Westerbeek (eds.), Recalling the Indies: Kebudayaan Kolonial dan Identitas Poskolonial (Yogyakarta: Syarikat Indonesia, 2004), hal. 23. 
pelapisan sosial, dan pada sisi lain segregasi justru memperlemah paradigma inklusivisme.

Struktur liyan memang dikehendaki oleh pemerintah Belanda untuk memperlemah Islam. Tindakan yang dilakukan Belanda adalah untuk melindungi modal usaha yang sudah tertanam di berbagai industri perkebunan, eksplorasi (perminyakan dan pertambangan), serta industri pabrikan. ${ }^{46}$ Implikasi penerapan struktur liyan dalam kehidupan sosial adalah masyarakat hanya bisa bertumpu pada hierarkhi sosial politik maupun sosial budaya. Kedua kutub itu selalu berlawanan, dan sering menghasilkan gerakan radikalisme keagamaan.

Sepanjang abad XIX politik di Vorstenlanden bagai benang kusut akibat tidak berdayanya aristokrat berhadapan dengan pemerintah Belanda. Kondisi ini mendorong Abd al-Samad al-Palimbani mengirim surat dari Mekkah kepada tiga raja Jawa (Paku Buwana III, Hamengku Buwana I, dan Mangkunegara I) untuk melancarkan perang sabil. ${ }^{47}$ Perang sabil simbolisme sikap anti Barat. Bahasa politik Abd al-Samad al-Palimbani merujuk pada simbol-simbol menggugah perlawanan, akibat sikap hegemonik Barat mengeksploitasi sumber ekonomi pribumi. ${ }^{48}$ Eksploitasi itu memperlemah subsistensi ekonomi, bahkan menjadi faktor dominan disintegrasi geo-politik.

Surat Abd al-Samad al-Palimbani tonggak sejarah yang membuktikan adanya intervensi dari luar yang meminta raja-raja berperang sabil. Permintaan surat itu telah membangun kesadaran para keturunan aristokrat yang disantri bahwa Muslim Jawa adalah bagian dari masyarakat Islam Dunia, dan perang sabil yang disarankan adalah sebuah dukungan dari masyarakat Islam Dunia yang tidak menghendaki proses eksploitasi ekonomi atau eksploitasi sumber alam yang lebih dari Bumi Nusantara yang mayoritas beragama Islam. Pada sisi lain, sepulang Muslim dari menunaikan ibadah haji pada abad XIX, mereka menyalurkan pandangan revolusioner kepada tokoh masyarakat di Hindia Belanda. Pandangan revolusioner menjadi bahan evaluasi terhadap eksistensi kolonialisme Belanda. Para haji menumbuhkan kesadaran pentingnya hak me-

46 Robert van Niel, Munculnya Elit Modern Indonesia (Jakarta: Pustaka Jaya, 1984), hal. 110-117.

${ }^{47}$ M.C. Ricklefs, Yogyakarta di bawah Sultan Mangkubumi1749-1792, hal. 212.

48 Immanuel Wallerstein, The Modern World-System: Capitalist Agriculture and the Origins of European World-Economy in the Sixteenth Century (New York: Academic Press, 1976). 
nentukan nasib sendiri, dan politik Islam tidak hanya berfungsi sebagai kekuatan dinamik, tetapi juga sebagai kekuatan pemersatu bangsa.

\section{E. Menuju Persatuan Gerakan Politik}

Bila pada abad ke-16 hingga abad ke-17 descending of power menjadi tumpuan kekuatan politik oleh Raden Patah dan Sultan Agung, dan kemudian ditinggalkan pewaris tahta untuk mendalami sekularisme, tetapi realitasnya tidak merubah pandangan menuju ascending of power untuk membangun negara bangsa. ${ }^{49}$ Pemikiran ascending of power baru muncul pada awal abad ke-20. Ascending of power adalah representasi atmosfir demokrasi yang diperjuangkan kaum nasionalis hingga tercapai kemerdekaan Indonesia. Seluruh komponen politik, raja, aristokrat, ulama, intelektual, dan rakyat yang berpandangan protagonis ikut berjuang meraih kemerdekaan..$^{50}$

Ascending of power dapat berjalan bila para politisi menempatkan diri sebagai agen pemberdayaan, baik berkaitan dengan civic engagement maupun political engagement. Kedua faktor itu sangat berperan untuk mereformasi struktur sosial. Dalam ascending of power basis massa Islam menjadi tumpuan kekuatan pergerakan, tetapi tidak menjadi kekuatan formalisme atau ideologis. Islam adalah kekuatan substansial yang memberi sumbangan terhadap etika dan moral politik pada peran kenegaraan. ${ }^{51}$ Kekuatan substansial di atas adalah sebuah warisan sejarah, lebih lanjut Fealy mengemukakan: "in Malaysia, Islamisation has resulted in greater Islamism and legalism; in Indonesia it has had more pluralitic and liberal manifestations" ${ }^{52}$

49 Bryan S. Turner, Agama dan Teori Sosial, hal. 306-307; lihat Soemarsaid Moertono, Negara dan Usaha Bina Negara: Studi tentang Mataram II, Abad XVI Sampai XIX, terj. YOI (Jakarta: YOI, 1985), hal. 33-41

50 Sartono Kartodirdjo, "Berkembang dan Runtuhnya Aristokrasi Tradisional Jawa”, dalam Hans Antlov \& Sven Cederroth, Kepemimpinan Jawa: Perintah Halus, Pemerintahan Otoriter (Jakarta: YOI, 2001), hal. 37.

51 Zuly Qodir, Sosiologi Politik Islam: Konstestasi Islam Politik dan Demokrasi di Indonesia (Yogyakarta: Pustaka Pelajar, 2012).

52 Bernhard Platzdasch, "Introduction", in Bernhard Platzdasch \& Johan Saravanamuttu (eds.), Religion Diversity in Muslim-mayority States in Southeast Asia (Singapore: ISEAS, 2014), hal. 5 . 
Dasar pemikiran Fealy di atas tidak mengherankan bila awal abad XX muncul aristokrat protagonis sebagai agen pemberdayaan tanpa memandang perspektif etnisitas dan etnoreligius. Dia adalah Sayidin Malikul Kusno yang tidak butuh bahasa dan simbol politik, tetapi tindakan yang dilakukan untuk melepaskan belenggu sistem diskriminasi ekonomi, politik, dan sosial. Peran Sayidin Malikul Kusno (Paku Buwana X) dapat dianalisis melalui teori Antony Giddens ${ }^{53}$ dan Rom Harre. ${ }^{54}$ Dengan kesadaran protagonis itu, dia menginginkan Muslim berdaya, karena itu merelakan hampir seluruh fasilitas dan finansial yang dimiliki untuk pemberdayaan masyarakat.

Terdapat 27 lembaga yang difungsikan sebagai pemberdayaan Muslim, dan mampu menumbuhkan dinamika kehidupan Muslim. Di antara 27 lembaga adalah: (1) Mendirikan Madrasah Mamba'ul Ulum, HIS Kasatryan, dan HIS Parmadi Putri dan Taman Kanak-Kanak Parmadi Siwi; (2) Rijksstudiefonds untuk abdi dalem berbakat; (3) Bank Bandhalumaksa; (4) Renovasi pasar Pasar Gedhe Hardjonegoro untuk penguatan ekonomi; (5) Rumah Sakit Kadipala dan Apotik Pantihusada; (6) Pembangunan Jembatan Jurug untuk akses ekonomi tiga kabupaten; (7) Pemindahkan Paheman Radya Pustaka di Jalan Slamet Riyadi sebagai tempat diskusi budaya; (8) Taman Hiburan Sriwedari; (9) Pembangunan Rumah Wangkoeng untuk memberi keterampilan buruh migran; (10) Memberi dukungan kepada SI dan BO; dan (11) Mendirikan lembaga pedalangan dan pertukangan.

Dalam teori Thorstein Veblen, pemberdayaan pendidikan untuk peningkatan kecerdasan dan mampu menghadapi perubahan sosial. Dengan pemberdayaan pendidikan diharapkan dapat menekan kesenjangan sosial antara the leisured class (kelas menengah) dan kelas bawah. Menguatnya kelas menengah berfungsi sebagai kohesi sosial, dan kohesi itu dimaknai sebagai kemampuan

53 Teori strukturasi Anthony Giddens, peran agen sangat kuat dalam mereproduksi kondisi sosial yang ditampilkan melalui kebijakan publik. Ada tiga faktor utma yang diindikasikan Giddens: (I) memiliki jangkauan pengetahuan, (2) merelakan fasilitas yang dimiliki untuk digunakan rakyat, dan (3) tindakan politik yang dilakukan bertumpu pada tujuan tertentu demi kemaslahatan rakyat. Lihat Anthony Giddens, The Constitution of Society: Teori Strukturasi untuk Analisis Sosial (Pasuruan: Pedati, 2004), hal. 3-17.

54 Rom Harre menyebutkan dalam merekonstruksi tindakan agen perlu kiranya mempertanyakan: (1) sejauh mana gagasan agen dapat mendorong perubahan sosial, (2) apakah gagasan agen merupakan prinsip baru yang dapat ditempatkan dalam suasana baru, (3) bagaimana cara mewujudkan. Lihat Christopher Lloyd, Explanation in Social History (Oxford, UK: Basil Blackwell, 1986), hal. 268-269 
dalam mengatasi perubahan sosial. ${ }^{55}$ Perubahan terjadi bila individu terbiasa berpikir secara formal. Kebiasaan itu bisa menjadi lahan kontemplasi dan refleksi terhadap relaitas sosial ekonomi dan politik.

Di Jawa ada tiga kota yang menunjukkan kemandirian dan keswasembadaan yang dikelola oleh masyarakat. Kota itu Surakarta, Yogyakarta dan Pekalongan. Tiga kota itu meupakan segitiga kekuatan ekonomi yang menopang pergerakan kebangsaan. ${ }^{56}$ Di Surakarta elit modern maupun intelektual tumbuh sebagai kelompok sosial baru, sehingga keduanya adalah kelompok sosial sekaligus kelompok politik yang menguasai cakrawala kehidupan kota. $^{57}$

Kelompok masyarakat yang mandiri dan swasembada di tiga kota sebagian besar Muslim dan pendukung organisasi Islam, SI, sebuah organisasi bersifat kota, reformis, dan dinamis. ${ }^{58}$ Kaum intelektual dengan kekuatan ekonomi yang dimiliki bergabung dalam organisasi itu baik secara individu maupun kelompok. Dalam organisasi politik itu mereka menciptakan struktur interaksi, karena itu pergerakan lokal di Surakarta menciptakan kekuatan politik nasional menghadapi hegemoni kolonial Belanda.

\section{F. Penutup}

Lekatnya Islam dan politik dalam perspektif descending of power maupun ascending of power sekadar alat politik. Islam memiliki solidaritas tinggi, dan solidaritas bisa berubah menjadi kekuatan politik ketika terrepresi secara terus menerus. Ketika kekuasaan politik sukses diraih timbul faksionalisme antarpolitisi. Karena itu, politik Islam selalu diselimuti faksi dan friksi, dan mudah dihempas oleh kekuatan politik lain.

Relasi ulama dan elit politik dalam bingkai descending of power tidak mungkin berlangsung lama karena elit tidak menghendaki kekuasaan Illahiah terbagi. Faktor utamanya ulama memainkan dan memelihara kongregasi politik. Peran

55 Selo Sumardjan, Perubahan Sosial di Yogyakarta (Yogyakarta: Gadjah Mada University Press, 1981), hal. 312-313.

56 Kuntowijoyo, "Muslim Kelas Menengah Indonesia dalam Mencari Identitas", Prisma, No. 11, November 1980, hal. 35.

57 Ibid., hal. 36.

58 Ibid., hal. 37. 
kongregasi itu dipersepsikan sebagai tandingan, akibatnya mereka direpresi raja, dan menyingkir dari pusat kekuasaan. Ulama berperani sebagai cultural broker bagi masyarakat pedesaan.

Realitas sejarah menunjukkan Islam memang lekat dengan dunia politik, tetapi hampir seluruh ulama di Nusantara menolak Islam sebagai ideologi negara. Pergerakan abad XX menampilkan kesadaran dan menuntut hidup bersama dalam suasana demokrasi. Demokrasi adalah wujud ascending of power yang menuntut tersedianya: (1) Pembagian kekuasaan, (2) Konstitusi yang melindungi etnisitas dan religiositas tanpa dibalut oleh diskrimisasi sosial, (3) Ideologi yang disepakati pendiri negara dipraktikkan sebagai perlindungan terhadap etnisitas dan religiositas. Menjadi naif, bila bersikukuh mengubah ideologi Pancasila dengan formalisme Islam.

\section{DAFTAR PUSTAKA}

Abdullah, Taufik. 1987.Islam dan Masyarakat: Pantulan Sejarah Indonesia.Jakarta: LP3ES.

Adlin, Alfathri.2006. Menggeledah Hasrat: Sebuah Pendekatan Multi Perspektif, Yogyakarta: Jalasutra.

Antlov, Hans \& Sven Cederroth (eds.). 2001. Kepemimpinan Jawa: Perintah Halus, Pemerintahan Otoriter. Jakarta: YOI.

Atsushi,Ota, Okamoto Masaaki, and Ahmad Suaedy (eds.). 2010. Islam in Contention: Rethinking Islam and State in Indonesia, Jakarta: Wahid InstitueCSEAS Kyoto University-CAPAS Nanyang.

Azra, Azyumardi.2004. Jaringan Ulama Timur Tengah dan Kepulauan Nusantara Abad XVII dan XVIII: Akar Pembaharuan Islam Indonesia. Jakarta: Prenada Media.

Azra, Azyumardi.2002. Historiografi Islam Kontemporer: Wacana, Aktualitas, dan Aktor Sejarah. Jakarta: Gramedia Pustaka Utama.

Bruinessen, Martin van. 2012. Kitab Kuning, Pesantren dan Tarekat. Yogyakarta: Gading Publising.

Cote, Joost \& Loes Westerbeek (eds.). 2004. Recalling the Indies: Kebudayaan Kolonial dan Identitas Poskolonial. Yogyakarta: Syarikat Indonesia. 
Deqy, Teungku Sayyid. 2014. Korpus Mapur dalam Islamisasi Bangka. Yogyakarta: Ombak.

Eickelman, Dale F. \& James Piscatori. 1998. Politik Muslim: Wacana Kekuasaan dan Hegemoni dalam Masyarakat Muslim. Yogyakarta: Tiara Wacana.

Florida, Nancy K.. 2003. Menyurat yang Silam Menggurat yang Menjelang: Sejarah sebagai Nubuat di Jawa Masa Kolonial. Yogyakarta: Bentang Budaya.

Giddens, Anthony. 2004. The Constitution of Society: Teori Strukturasi untuk Analisis Sosial. Pasuruan: Pedati.

Graaf, H.J. de. 1986. Puncak Kekuasaan Mataram: Politik Ekspansi Sultan Agung. Jakarta: Pustaka Grafitipers.

Graff, H.J. de \& Th. Pigeud. 1985. Kerajaan-kerajaan Islam di Jawa: Peralihan dari Majapahit ke Mataram. Jakarta: Grafiti Pers.

Gunawan, Asep (ed.). 2004. Artikulasi Islam Kultural: Dari Tahapan Moral ke Periode Sejarah. Jakarta: Raja Grafindo Persada.

Houben, Vincent J.H.. 2002. Keraton dan Kompeni: Surakarta dan Yogyakarta 18301870. Yogyakarta: Bentang Budaya.

Johns, A.H..1961. "Muslim Mystics and Historical Writing", dalam D.G.E. Hall (ed.) Historians of South East Asia. London: Oxford University Press.

Kamdani (peny.). 2007. Islam dan Humanisme: Aktualisasi Humanisme Islam di Tengah Krisis Humanisme Universal. Yogyakarta: Pustaka Pelajar.

Kartodirdjo, Sartono. 1978. Protest Movement in Rural Java: A Study of Agrarian Unrest in the Nineteenth and Early Twentieth Centuries. Kuala Lumpur: Oxford University Press.

Khaldun, Ibn. 1986. Muqaddimah. Jakarta: Pustaka Firdaus.

Kuntowijoyo. 1980. “Muslim Kelas Menengah Indonesia dalam Mencari Identitas". Prisma, No. 11, November 1980.

Latif, Yudi. 2005. Inteligensia Muslim dan Kuasa: Genealogi Inteligensia Muslim Indonesia Abad ke-20. Bandung: Mizan.

Lloyd, Christopher. 1986. Explanation in Social History. Oxford, UK: Basil Blackwell.

Maliki, Zainuddin. 2004. Agama Priyayi: Makna Agama di Tangan Elite Penguasa. Yogyakarta: Pustaka Marwa.

Mas'ud, Abdurrahman. 2004. Intelektual Pesantren: Perhelatan Agama dan Tradisi. Yogyakarta: LKiS. 
Millie, Julian. 2009. Splashed by the Saint: Ritual Reading and Islamic Sanctity in West Java. Leiden: KITLV Press.

Mujani, Saiful. 2007. Muslim Demokrat: Islam, Budaya Demokrasi, dan Partisipasi Politik di Indonesia Pasca-Orde Baru. Jakarta: Gramedia Pustaka Utama.

Munawar-Rachman, Budhy. 2004. Islam Pluralis: Wacana Kesetaraan Kaum Beriman. Jakarta: Sri Gunting, Raja Grafindo Persada.

Niel, Robert van. 1984. Munculnya Elit Modern Indonesia. Jakarta: Pustaka Jaya.

Nieuwenhuijse, C.A.O. van.1958. Aspects of Islam in Post-Colonial Indonesia. The Hague and Bandung: W. van Hoeve.

Norris, Pippa \& Ronald Inglehart. 2009. Sekularisasi Ditinjau Kembali: Agama dan Politik di Dunia Dewasa Ini. Tangerang: Alvabet \& Yayasan Wakaf Paramadina.

Piliang, Yasraf A. 2006. Transpolitika: Dinamika Politik di dalam Era Virtualitas. Yogyakarta dan Bandung: Jalasutra.

Qodir, Zuly. 2012. Sosiologi Politik Islam: Konstestasi Islam Politik dan Demokrasi di Indonesia, Yogyakarta: Pustaka Pelajar.

Remmelink, Willem. 2002. Perang Cina dan Runtuhnya Negara Jawa 1725-1743, Yogyakarta: Jendela.

Ricklefs, M.C.. 1998. "Islamising Java: The Long Shadow of Sultan Agung", Archipel, Vol. I, No. 56, 1998.

Ricklefs, M.C..1998. The Seen and Unseen Worlds in Java 1726-1749: History, Literature and Islam in the Court of Pakubuwana II, Honolulu: Allen \& Unwin, and University of Hawai'Press.

Ricklefs, M.C..2002. Yogyakarta di bawah Sultan Mangkubumi1749-1792. Yogyakarta: Mata Bangsa.

Sanit, Arbi. 1982. Sistem Politik Indonesia: Kestabilan, Peta Kekuatan Politik dan Pembangunan. Jakarta: Rajawali Pers.

Setiono, Benny G. 2008. Tionghoa dalam Pusaran Politik. Jakarta: Trans Media.

Soebardi, S.. 1971. "Santri-religious Elements as Reflected in the Book of Tjentini", Bijdragen tot de Taal-, Land-en Volkenkunde (BKI), No. 127.

Soebardi, S.. 2004. Serat Cabolek: Kuasa, Agama, Pembebasan. Bandung: Yayasan Nuansa Cendekia.

Soemarsaid Moertono. 1985. Negara dan Usaha Bina Negara: Studi tentang Mataram II, Abad XVI Sampai XIX, terj. YOI.Jakarta: YOI. 
Steenbrink, Karel A.. 1984. Beberapa Aspek tentang Islam di Indonesia Abad ke-19. Jakarta: Bulan Bintang.

Sumardjan, Selo. 1981. Perubahan Sosial di Yogyakarta. Yogyakarta: Gadjah Mada University Press.

Suryawan, I Ngurah. 2010. Genealogi Kekerasan dan Pergolakan Subaltern: Bara di Bali Utara. Jakarta: Predana Media.

Tempo, Edisi 5 - 11 Agustus 2013.

Turner, Bryan S..2006. Agama dan Teori Sosial. Yogyakarta: Ircisod.

Wallerstein, Immanuel. 1976. The Modern World-System: Capitalist Agriculture and the Origins of European World-Economy in the Sixteenth Century. New York: Academic Press. 